\title{
The defence of fortified ruins on the Italian coast Andrea Ugolini ${ }^{a}$, Chiara Mariotti ${ }^{\mathbf{b}}$

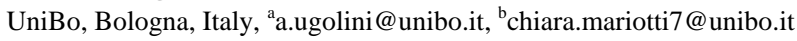

\begin{abstract}
The essay, as part of a more extensive scientific research, aims at evaluating the theoretical and technical issues linked to the active conservation of fortified heritage in ruins present on the Italian coast. Through the analysis of some exemplary projects, the study will describe the relationship between the architecture and the context, deal with the theme of the absence (lacuna) and the relative interventions, reflect upon the different ways of interpretation and reinstatement, look into the design and management of the vegetation and, last but not least, define strategies and processes for a planned preventive maintenance of these important testimonies of the past.
\end{abstract}

Keywords: ruins, landscape, active conservation.

\section{Fortified ruins. Issues of conservation}

A historical and artistic value has always been attributed to classical ruins. The same cannot be said for fortified ruins, at least not until 1964. Born for peacekeeping purposes and excluded from safeguarding projects for a long time, fortifications became "monument" only after the drawing up of the Venice Charter. The first article of this international document on conservation and restoration, modified the definition of monument including new categories of buildings from the past with, in first place, buildings for static defence: «The concept of an historic monument embraces not only the single architectural work but also the urban or rural setting in which is found the evidence of a particular civilisation, a significant development or an historic event» (the Venice Charter, 1964). Since 1964 a new history of fortified architectures has begun: the story of their conservation.

In Italy, the safeguarding of fortified heritage is inseparably linked to the theoretical and practical activity of Piero Gazzola, one of the main drafters of the Venice Charter. Eclectic figure of the second half of the Twentieth Century, Gazzola battled to gain the recognition, conservation and the valorisation of fortified buildings. Through the propulsive action of international and national institutes Internationalen Burgenforshung Institut (IBI) and Istituto Italiano dei Castelli (The Italian Institute for Castles) - he fostered and guided the process of awareness aimed at safeguarding this important field of historical testimony from neglect or abandon, trying to confer to these buildings a new and practical function in modern life. In compliance with what was sanctioned under article 5 of the above-mentioned Charter for Restoration, the architect supported the need for active protection of monuments guaranteed through their use. Conditio sine qua non for the survival of ancient buildings, this puts us face to face with the inevitable question: what are the uses for fortified buildings? And, even more important, what functions can their ruins have?

To the theme of ruins, intended as the last remains of a monument characterized by its 
prevailing documental value, Gazzola dedicated one of his masterly writings, published in the journal "Castellum" - the scientific review by the Istituto Italiano dei Castelli - in 1967. Retracing the paths that marked the evolution in the approach to ruins from the Middle Ages to the Modern Age, the author put forward a series of interesting considerations still of topical interest today.

The emblem of the spirit of monumentality, witness to the historical continuance of events to mankind and element for confrontation, the ruin was matter of veneration for historians and intellectuals of the fifteenth century, object of speculation for histographers and collectors in the sixteenth century, symbol of the mortal condition of humanity and key to the interpretation of mysteries of antiquity between the seventeenth and the eighteenth century. To the countless nuances which have characterized ruins over the centuries, Gazzola added a description, or better still, a denouncement referred to his contemporaneous situation. «Among the symptoms of spiritual avarice of our day, we can indicate as significant, the absence of interest in ruins. [...] a term mainly used in a metaphoric sense to indicate something decrepit and by now without resources» (Gazzola, 1967). Fragment of a wall, relic of a castle or piece of a fortified hamlet, the ruin demands an immediate redeeming from its false condition of ex-monument. After all, as recommended by ICOMOS in 1964, «castles and their ruins constitute historical documents of priceless value; their conservation and protection is consequently essential for the safeguarding of cultural heritage».

The plea for conservation of fortified heritage cannot but become more urgent in the case of buildings reduced to ruins, a condition in which many of the towers built along more than 7000 kilometres of Italian coast can be found today. Intrinsically tied to the geography of places and strategically located on the territory, though in advanced conditions of abandon and decay, such structures constitute an essential and emblematic example.[CM].

\section{The defence system of coastal towers in Italy}

Fortified towers have marked the Italian seaside since Roman times, from when the central role and the considerable development of coasts in relation to the whole Mediterranean area became a strategic and military problem increasingly relevant. Displaced in such a way as to constitute an organized and cohesive defence system against any form of piracy, their task was to control the profile of the coast and indicate any dangers. The so-called "alarm" towers, have modified their conformation and physiognomy over the centuries: now cylindrical, tall and thin now on a quadrangular base with barbican more or less accentuated and brattice in defence or as simple ornament. Often structured on 2 or 3 levels, they have assumed volumetric configurations sometimes very complex and always characterizing in relation to the geographical and historical context in which they were built.

Built directly on the sea or in prominent positions near the coast, such structures result always to be in sight of one another, so as to guarantee an efficient and permanent system of control. The Normans, Swabians and the Angevins fortified the coasts in the south of Italy, throughout the Middle Ages, but only after the fall of Constantinople (1453), a consistent operation of arranging a system can be seen for this type of architectures - which by themselves, were considered incapable of guaranteeing a safe and constant defence against the disembarking of barbarians -. Significant was the fact that the dense protection activity of the coast undertaken by Spanish rulers, like the Viceroy of Naples don Pedro of Toledo halfway through the 16th century, was imitated by all the other Italian states. Present both on the southern coast of the Adriatic and on the Tyrrhenian, many coastal towers - although preserving their defence function - in the 18th century became customs barriers to prevent smuggling and were often transformed into garrisons for health protection. In the twentieth century, during the First and Second World War, some of them were taken over as fixed stations for soldiers. 
The coastal towers, like the major part of fortified architecture were excluded from the laws for safeguarding of the Italian State: in short they were not considered as monuments. Fortunately though our coasts for some time have been subject to landscape protection and the coastal towers have been able to exploit indirectly this privilege. To this must be added the predisposition of these buildings to maintain integrated over time an analogous function to their original one. The coherent use in fact unusual in the case of buildings for defence, for many has been the only resource against abandon, the only guarantee of survival: from watchtower to signal tower for our military Navy, from coastal protection against the Saracens to smuggling centres, from the headquarters of Customs Guard to headquarters of the current Finance Police.

At present in Italy there are more than 750 buildings for coastal defence without counting those lost. For example it is interesting to remember that in the Kingdom of Naples, which as is known, corresponds to the present day Abruzzi, Molise, Campania, Apulia, Basilicata and Calabria including part of today's southern and eastern Latium there were 379 towers, according to a census dating back to 1748 . In the Lands of Otranto there were 88 exemplars, already reduced by half in the mid Seventies to 66 , of which 50 in a state of ruin or complete abandon and only 16 well conserved and still inhabited (Faglia, 1978).[AU]

\section{How have the ruined towers been conserved?}

Although current practices tend too often to confine ruins to the margins of architecture, today critical thinking appears to be without doubt at the centre of this discipline. Justifications, criticism and condemnation accompany the numerous interventions which try to govern a project poised between past, present and future in the hope of identifying a convincing limit between what has been and what will be. Finding a way through the several declinations employed by the interventions on the pre-existence of the state of ruin, the notes that follow, propose a rapid but essential careful examination of the projects realized in the last quarter of century of the fortified towers along the Italian coast. Part of a more extensive scientific research the authors are carrying out on the subject, the study without any claim to exhaustiveness, limits itself to describing - as being symptomatic $\quad-$ the different methodologies of approach to the conservation of defence remains that characterize the culture of restoration on our territory. In the complete awareness of the reductive value of every process of classification, the study cases we have decided to present summarize the double tendency that distinguishes the Italian experience, marked on one side by denial, and on the other, by the acceptance of the ruin as a fragment. [CM]

\subsection{The denial of ruins as architectural fragment}

The first and most frequent tendency is represented by the denial of ruins as architectural fragment. Such a position, aimed at total reconstruction of the architectural work, is directed at restoring the physical entirety, the figurative continuity and iconographical recognisability. In contrast with the assumptions of the Brandian theory, the fragment is considered incapable of conserving the potential unity of the original work and is, as a direct consequence, condemned to death: at a material level, by means of a more or less partial reintegration; at an intellectual level by means of its reinvention (Fiorani, 2009). Occasion for bold and often anachronistic restorations, ruins are in this way taken back to a completed dimension in terms of space and in terms of functionality which, however, cancels essence and value. Assuming it as possible, from an ethical and technical point of view, such an operation reduces the ruin to a simple presupposition for the reconstruction, a mere pretext for the rewriting - nearly always forced of history.

Within this first reconstructive tendency, so to speak, it is possible to recognize two different operational directions: a return to the original 
form and a rebuilding of the ancient accompanied by the new.

Frequently tribute to a reassuring idea of the Middle Ages, a return to the primitive form refuses the interpretation of the ancient texta limiting itself to its understanding and translating it into a faithful imitation of the shapes, materials and building techniques. Concerning this, reconstructions carried out starting from the Thirties, of fortified towers with battlements, are numerous. Permeated by economic consideration or influenced by an incorrect interpretation of the pre-existence, the re-integration of missing parts sometimes produces results that profoundly alter the historical data. Models of this, are the widespread formal re-compositions and reinterpretations in existence, for example the Minervino Tower (XVI cent.) in Santa Cesarea Terme, along the eastern coast of Salento, where new incongruent coloured coatings are characterized by marks and portions with exposed faces.

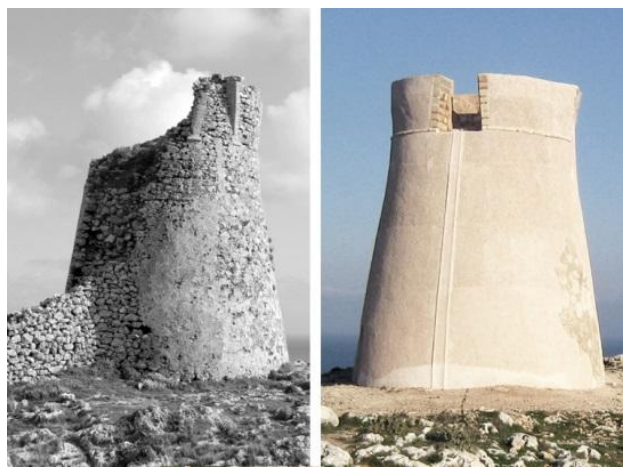

Fig. 1- The Minervino Tower

Little affected by removal interventions, a project on a fortified ruin often unites the analogical-stylistic integration with the inserting of new, now openly modern, as in the case of the Boraco Tower (XVI cent.) in Manduria in Apulia, now ostentatiously self-referential and also the case of the Su Fenugu Tower (XVI cent.) in Tower delle Stelle in Sardinia. In the first case, side by side with the careful philological, material and formal reconstruction of the upper portions - which however remain recognizable and charming - there is the contemporaneous insertion of the outside staircase: accurate and distinguishable, the addition guarantees continuous use, does not alter the authenticity of the historical building and strengthens the harmony of the new composition.
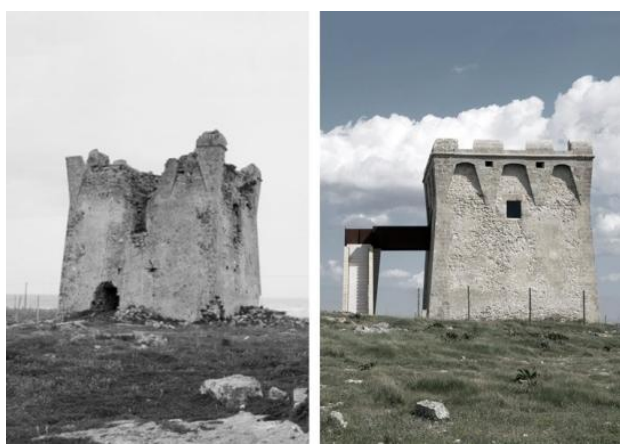

Fig. 2- The Boraco Tower

In the second case, instead, the new cancels the ancient, exhibiting only itself: extravagant and of banal distinguishability, the helical outside staircase in steel is in direct contrast with the existing, devaluing without distinction both past and present.
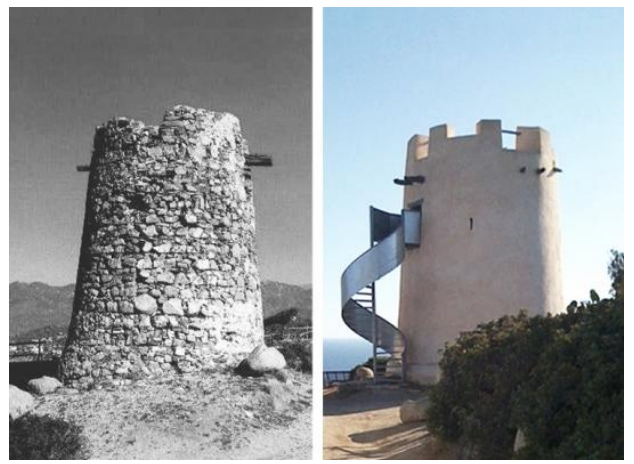

Fig. 3- The Su Fenugu Tower

Therefore we believe that in the complex dynamics between ancient and new the modern insertion must establish a dialectical comparison between the ruins and new additions renouncing the search for a conflicting relationship designed to leave to the reversibility of the interventions alone the task of giving an alibi to projects, in reality insufficient from a critical point of view in the first place - but also technical and functional (Serafini, 2005). [CM] 


\subsection{Acceptance of ruins as architectural fragment}

Dominant reconstruction tendencies, contrariwise, are placed side by side with a less diffused but undoubtedly more prudent position, based on acceptance of the ruin as fragment. No less complex than the previous, conservation of the ruin itself arises from acknowledgement of the implicit value of the architectural remains themselves and is substantiated through the legitimation and enhancement of their incompleteness. The invasive operation of recomposition as above in this way leaves space for a series of interventions based on surviving materials, moving the objective from the reconstruction of a missing unit to the conservation of what remains, where the adding of an element, often necessary, results however accurate and finalized at protecting the status of ruin and not a self-referentialism of the designer.

From this point of view the same operations of reinforcement and the only "apparent" neutral reintegration of the lacuna result to be in reality, architectural gestures, subject to all intents and purposes to laws which regulate the matter. Indeed the refining of the language - materials, weavings, design and colours - adopted in the additional element, belongs to restoration, be it the integration of missing parts or structural support. Control of such language results essential for measuring the delicate relationship between the work and its integration in order to guarantee the stratigraphical recognisability of such palimpsest and to avoid at the same time that the distinction accentuates to the point of becoming hiatus. In the Del Monte Tower in Scauri in Latium (end of XVI cent.), for example, the reintegrations of lacuna, although carried out to perfection in stone similar in size and shape to the existing (as can be seen in the photos of the building site), are subsequently covered in plaster - the only parts of the Tower subjected to such treatment - in respect of an already satisfactory recognisability of the intervention.

Or once again in the case of the Foxi Tower in Quartu Sant'Elena (XVI-XVII cent.) a disorganized and intentionally different masonry device for reintegration can be witnessed which ends up altering the reading of the building instead of keeping to a measured gradient of diversity, the laying and sizing of materials which would anyhow make the lacuna recognizable.
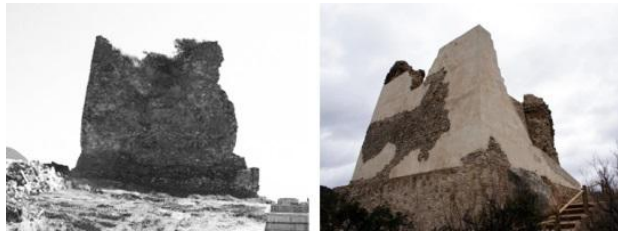

Fig. 4- The Del Monte Tower

Contrasting the decaying of ruins, when, above all there is the threat of an acceleration in the decay, presents the designer with difficult and not always suitable choices. If the traditional building of buttresses constitutes one of the most ancient forms of reinforcement, it is also true that their reinterpretation "in false ruins" is not very convincing as can be observed in the regularized outlines of the Della Serpe Tower (end XV) on the cliffs south of Otranto, in Apulia. Here, the designer has completely rebuilt the base of the construction and made two buttresses in stone with a false eroded outline, which he has then plastered, engraving on the surface the design of the face.
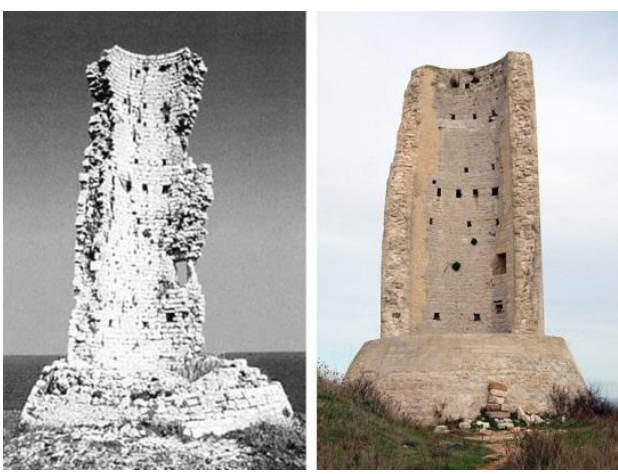

Fig. 5- The Della Serpe Tower

In a different way the Tower of the Gallinaro in Cipressa (XVI cent.) along the Ligurian coast, was subject to a different approach, where although improving the static performance of the Tower with accurate interventions of protection and targeted works of substructuring, the system 
of cracks, the deformations and the "ruin contour" of the construction have been conserved. After the interventions, the Tower has maintained unaltered its stratigraphical readability which guarantees to it délabré heterogeneity and a picturesque image directly from the ruins without renouncing to its essential safety.

Finally, analogous respectful conservation and careful control of the language characterize the interventions on the ruins of the medieval Tower of the Ziro (XV cent.) situated in front of Amalfi. In a monument that has become a ruin, its collapse often makes internal paths impracticable and the following of an itinerary undoubtedly represents «the minimum condition for use» (Bellini, 1990). The intervention carried out with limited financial resources has seen, alongside accurate and calibrated interventions of material conservation, the insertion of a new staircase with a bolted structure - therefore reversible - which consolidates and clamps the ancient walls of the tower finding space between the still integral parts of vaults and attics, in their turn covered with chestnut shafts, varnished white. Here the contrast of the cause of deterioration accompanied by the alleviation of the effects through defence, favours the use of the tower and, in the end, its conservation. [AU]

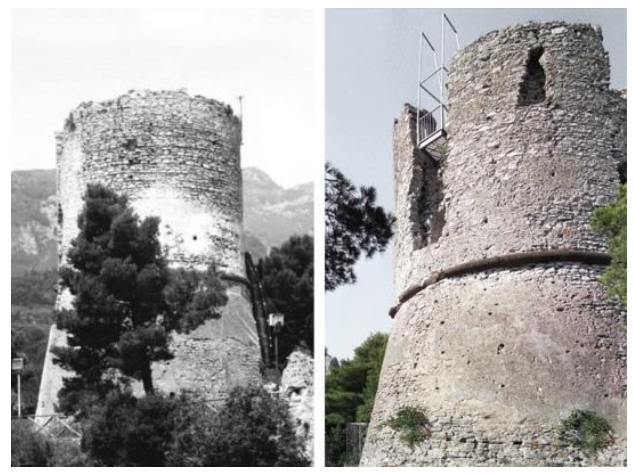

Fig. 6- The Tower of the Ziro

\section{Conserving ruins. Principles and practice}

A critical reading of Italian projects demonstrates, though in the extreme synthesis imposed by the nature of the essay, that strange polyphony within the discipline marked by a not always peaceful coexistence between, on one hand, the advocates of rebirth, and the return to ancient splendour, and on the other, the supporters of the value of absence and suspension. (Fiorani, 2009). With regard to the often contradictory complexity tied to the theme of ruins, a clarification must be made: the fragment is itself the first paradox. From the state of ruin of a building derives in fact, the lack of compliance with that fundamental parameter which distinguishes architecture from other forms of art, the functional parameter. The last remnant of history and building material, the ruin, reaches us like a lifeless body, as functionless architecture. Already an antinomy, the idea of "functionless architecture" becomes more acute in the specific case of defence structures, exposed to the reasons for functionality, more than any other form of building. Once safe bastions, today mounds of defenceless rubble, fortified ruins lie in isolation along the coasts of the Italian peninsula or in the nearby hinterland waiting in silence for their revenge.

In reality rather than revenge or redemption it would be more appropriate to talk about «animation», intended as a «qualified introduction of the monument to the present» (Gazzola, 1979). In equilibrium between the countless applications of the project, the intervention on the pre-existence of the state of the ruin, should find the strength to admit - if the circumstances impose it - the impossibility of resorting to active protection through the insertion of a new function. Once again in compliance with what was defined by ICOMOS in 1964, we need indeed to emphasize that «the integration of castles and their ruins into modern life, does not necessarily mean their use for practical purposes». Without falling into the pitfall of mummification, the conservation action should therefore insist on the possibility of reactivating the ruins indirectly as a «supporting actor on the environmental scene» (Gazzola, 1968). Forever part of the landscape, fortified ruins would thus overcome the condition of passive encumbrance to become a centre of attraction, not only background for tourist initiatives, but constant occasion for reflections 
and interpretations. It is just in these terms that the writers intend conservation of fortified ruins.

The valorisation of the towers present along the Italian coastline should therefore proceed from what has guaranteed their survival until today, the coastal landscape. Exploiting the advantage imposed by environmental restrictions, such structures found themselves inside a protected area that has permitted only limited transformations. Yet the cases analyzed have demonstrated how negligent interventions, carelessness and abandon have been the cause of consistent processes of transformation, sometimes bordering on transfiguration. To quote Gilles Clément, the scene we are faced with today is that of a «third landscape»: frequently marked by the absence of human activity and often reported in a symbiotic way to the vegetation structure, towers in our coastal defence system no longer represent just a nostalgic place to spellbind us, but rather a potential resource. An open work par excellence, the ruin should require minimum material exertion - cleaning and control of vegetation, structural defences, protection of surfaces - and the greatest attention to the research for a new system unit in which to reposition the single fragments along the memory circuit.

Therefore we imagine a project inside and around the ruin where a conservative attitude aimed at maintaining as much historical material as possible welcomes the contemporary insertion minimized in quantity, maximized in quality and above all reversible. Considering as an added value not only the stratigraphical diversity of the architecture, but also the ecological diversity of the coastal landscape, we believe that a project which pays attention to planned preventive maintenance and management of the building and the vegetation should be encouraged, in an attempt to support the richness of the signs and meanings gained by the place. Recent examples in fact demonstrate how a controlled coexistence between ruins and vegetation, the combination of which constitutes one of the main identification elements of the place, is possible only if it is administered through a series of investigations on the compatibility and alterations produced by the different botanical species (Ugolini and Matteini, 2013).

In conclusion, from the brief notes presented here and beyond any solution that the contemporary design has experimented and will experiment in the future, we would like to stress that active conservation of fortified ruins - but also their landscape context - remains a difficult and controversial subject. An inclusive and interdisciplinary project, directed at the defence of the complexity of what remains, the control of its inevitable change and, not least, the conservation of its feasibility even when the ancient text appears to us without meaning.

[AU, CM]

\section{Notes}

Andrea Ugolini and Tessa Matteini are both involved with issues related to the active conservation of archaeological landscapes and buildings in the condition of ruins in the academic and professional field; Chiara Mariotti is drawing up, as part of her $\mathrm{PhD}$ in Architecture at the University of Bologna, a thesis with the title Difendere la difesa. Architetture fortificate, progetto e tutela dalla Carta di Venezia ad oggi.

\section{References}

Bellini A. (1990). "Architettura uso e restauro" in Pirazzoli N. (ed.), Restauro architettonico: il tema dell'uso. Essegi Ed. Ravenna. pp. 17-42.

Faglia V. (1978). "La difesa costiera nel regno di Napoli. Ricupero della funzione" in Castella n. 18, Architettura Fortificata, Atti del $I^{\circ}$ Congresso Internazionale, Piacenza Bologna 18-21 marzo 1976. Istituto Italiano dei Castelli Ed. Bologna. pp. 131-135.

Fiorani D. (2009). "Architettura, rovina, restauro" in Barbanera M. (ed.), Relitti riletti. Metamorfosi delle rovine e identità culturale. Bollati Boringhieri Ed. Torino. pp. 339-354.

Gazzola P. (1967). "La difesa del rudere" in Castellum n. 5. Istituto Italiano dei Castelli Ed. Roma. pp. 5-14. 
Gazzola P. (1968). "La conservazione ed il restauro dei castelli alla luce della Carta di Venezia" in Castellum n. 8. Istituto Italiano dei Castelli Ed. Roma. pp. 81-96.

Gazzola P. (1979). "Restaurare?” in Castellum n. 20. Istituto Italiano dei Castelli Ed. Roma. pp. 69-76.

Leonardi P. (1991). Le torri costiere d'Italia. Vallecchi Ed. Firenze.

Serafini L. (2005). "La progettazione per gli edifici allo stato di rudere tra realizzazioni e questioni teoriche" in Varagnoli C. (ed.), Conservare il passato. Metodi ed esperienze di protezione e restauro nei siti archeologici, Atti del convegno Chieti-Pescara, 25-26 settembre 2003. Gangemi Ed. Roma. pp. 79-96.

Ugolini A. (ed.) (2010). Ricomporre la rovina. Alinea Ed. Firenze.

Ugolini A., Matteini T. (2013). "Design and active conservation of archaeological landscapes. New windows of research for an interdisciplinary reading" in Biscontin G., Driussi G. (ed.), Conservazione e valorizzazione dei siti archeologici. Approcci scientifici e problemi di metodo. Atti del convegno di studi Bressanone 9-12 luglio 2013. Arcadia Ricerche Ed. Marghera-Venezia. pp. $512-525$.

\section{Images}

Fig. 1- Before: http://www.torrimarittimedelsalento.it/19A_TorreMinervino.jpg [Accessed: 6th April 2015] After: http://upload.wikimedia.org/wikipedia/commons/b/b0/Torre_Minervino_(Santa_Cesarea_Terme).jpg [Accessed: 6th April 2015]

Fig. 2- Before: http://www.architetturadipietra.it/wp/wp-content/uploads/2013/08/boraco_4.jpg [Accessed: 26th March 2015]

After: http://www.architetturadipietra.it/wp/wp-content/uploads/2013/08/boraco_5.jpg [Accessed: 26th March 2015]

Fig. 3- Before: http://ospitiweb.indire.it/ camm0001/furat_2i_99_00/Image29.jpg [Accessed: 19th March 2015] After: Photo by Caterina Giannattasio, 2009.

Fig. 4- Before: Photo by Cesare Crova, 2007. After: Photo by Cesare Crova, 2009.

Fig. 5- Before: http://www.otrantoinforma.com/foto/foto_corchia/torre-del-serpe.jpg [Accessed: 19th March 2015] After: https://circolotandem.files.wordpress.com/2011/12/scarpantibus-18-12-2011-004.jpg [Accessed: 19th March 2015]

Fig. 6- Before: Photo by Giuseppe Fiengo, 2008.

After: http://www.archidiap.com/beta/wp-content/uploads/2014/09/32x.jpg [Accessed: 26th March 2015] 